\title{
Interactive comment on "Exploring wintertime regional haze in Northeast China: role of coal and biomass burning" by Jian Zhang et al.
}

Jian Zhang et al.

liweijun@zju.edu.cn

Received and published: 18 March 2020

Please see the attached file including the responses.

Please also note the supplement to this comment:

https://www.atmos-chem-phys-discuss.net/acp-2019-1025/acp-2019-1025-AC1-

supplement.pdf

Interactive comment on Atmos. Chem. Phys. Discuss., https://doi.org/10.5194/acp-2019-1025, 2020. 